\title{
Pharmacokinetic interaction of nitroxynil and cefoperazone in goats
}

\author{
Mohamed El-Hewaity \\ Department of Pharmacology, Faculty of Veterinary Medicine, University of Sadat City, 32897 Minoufiya, Egypt \\ E-mail: melhewaty@yahoo.com
}

Copyright $\odot 2015$ Mohamed El-Hewaity. This is an open access article distributed under the Creative Commons Attribution License, which permits unrestricted use, distribution, and reproduction in any medium, provided the original work is properly cited.

\begin{abstract}
The pharmacokinetic aspects of cefoperazone (CEFO) were investigated via intravenous (IV), and intramuscular (IM) injections in clinically healthy goats at a dose of $20 \mathrm{mg} / \mathrm{kg}$ b.wt. Goats were pre-treated with nitroxynil (25\%) or nitroxynil (34\%) subcutaneously in a dose $10 \mathrm{mg} / \mathrm{kg}$ b.wt, respectively. Cefoperazone was injected intramuscularly nine hours following anthelmintic administration, and blood samples were taken by jugular venipuncture at standardized intervals. Cefoperazone concentrations in serum were determined by microbiological assay technique. Goats pre-treated with nitroxynil $(25 \%)$ or nitroxynil $(34 \%)$ showed a significant decrease in serum cefoperazone level as compared to non-anthelmintic treated goats. The obtained data revealed that administration of nitroxynil in both concentrations negatively affected most of the cefoperazone parameters. In this respect, the elimination half-life $\mathrm{T}_{0.5(\mathrm{el})}, \mathrm{C}_{\mathrm{max}}, \mathrm{AUC}$, and the systemic bioavailability $(\mathrm{F} \%)$ were significantly decreased in both groups of nitroxynil-treated goats compared to non-anthelmintic treated goats. On the other hand, there were no significance differences between both nitroxynil (25\% and $34 \%)$ treated goats. Concomitant administration of nitroxynil (25\% and $34 \%$ ) with cefoperazone resulted in significant alterations in the disposition kinetic of cefoperazone in goats. Consequently, the interaction between nitroxynil and cefoperazone could be of clinical significance and may require monitoring and adjustment of cefoperazone dosage.
\end{abstract}

Keywords: Kinetic, Interaction, Nitroxynil, Cefoperazone, Goat

\section{Introduction}

Drug interaction is a common phenomenon, that impairs or exaggerates the proposed effect of one or both administered drugs. Therefore, researchers should pay attention to this problem so as to elucidate possible interactions between different drugs when it deemed necessary to coadminister them. An example of combination between antibiotics and anthelmintic drugs that may be used in veterinary medicine is the coadministration of cephalosporin and nitroxynil.

Cefoperazone is a semi-synthetic third generation, piperazine $\beta$-lactam antibiotics that possesses broad spectrum activity against aerobic and anaerobic gram-positive and gram-negative bacteria [1]. Cefoperazone is used in the treatment of bone and joint infections of horses [2], calf diseases such as diarrhea and pneumonia [3] and has good penetration into the pancreas indicating its usefulness for the prophylaxis and therapy of secondary pancreatic infections [4]. Only a few cephalosporins have a high biliary excretion, cefoperazone being one of them. Cefoperazone exhibits a longer half-life of elimination than older members of the group [5] and good penetration into organic bone [6].

Nitroxynil (4-Hydroxy-3-lodo-5-NitrobenOnitrile) is a potent anthelminthic from the family of substituted phenols that is utilized in ruminants for the control of trematodes, particularly for Fasciola hepatica. However, this anthelminthic has been widely utilized in the control of Haemonchus contortus (haemonchois) in sheep due to its effectiveness [7]. Probably, because this drug is strongly linked to plasmatic proteins, thereby promoting adequate tissue distribution and due to its slow elimination can be observed with the plasma of sheep as much as 48 days after a subcutaneous administration [8]. The increasing use of phenolic substitutes in the control of hemoncosis, particularily in cases of anthelmintic resistance to other drugs [9], associated with increased susceptibility of females in late pregnancy and lactation to parasitic infestation [10], and since nitroxynil passes the placental barrier reaching the fetus [11]. 
The pharmacokinetics of cefoperazone have been investigated in a number of animal species including unweaned calves [12], horse [13], dog [14], buffalo calves [15] and [16], cross bred calves [17] and [18] and sheep [19].

There is no available literature concerning the pharmacokinetic interactions between cefoperazone and nitroxynil in animals. Therefore, the purpose of this study is to determine the pharmacokinetic parameters of cefoperazone following a single intravenous and intramuscular administration at the dose of $20 \mathrm{mg} / \mathrm{kg} \mathrm{b}$.wt in goats, also to assess the effect of two different concentrations of Nitroxynil (25\% and 34\%) on disposition kinetics of cefoperazone in goats.

\section{Materials and methods}

\subsection{Drugs and chemicals}

Cefoperazone sodium powder (CEFOBID ${ }^{\circledR}$, produced by Smithkline Beecham Egypt LLc for Pfizer Egypt) was diluted with sterile water just prior to administration.

Nitroxynil was supplied in the form of injectable solution 25\% (DOVENIX, MERIAL, FRANCE).

Nitroxynil was supplied in the form of injectable solution 34\% (HEPANIL34, VETPHARM, and U.K).

Mueller-Hinton agar was purchased from Mast Group Ltd., Merseyside, UK.

\subsection{Animals}

Five clinically healthy, non-pregnant, non-lactating goats of 2-3 years old and Weighing 29-34 kg b.wt. Were used. Goats were kept indoors under good hygienic conditions, fed on barseem, Drawa and Concentrate. Water was provided ad-libitum. Animals were kept under observation for one month before, and between experimentation to ensure complete clearance of their bodies from any probable drug residues.

\subsection{Experimental design}

Four experiments have been carried out on 5 goats.

\subsubsection{Experiment 1}

Cefoperazone was administered into the right jugular vein at a dose of $20 \mathrm{mg} / \mathrm{kg}$ b.wt.

\subsubsection{Experiment 2}

Cefoperazone was administered into the gluteal muscle at a dose of $20 \mathrm{mg} / \mathrm{kg}$ b.wt.

\subsubsection{Experiment 3}

Nitroxynil 25\% (DOVENIX ${ }^{\circledR}$ ) was given subcutaneously at a dose of $10 \mathrm{mg} / \mathrm{kg} \mathrm{b.wt} \mathrm{nine} \mathrm{hours} \mathrm{before} \mathrm{intramuscular}$ injection of cefoperazone in a dose of $20 \mathrm{mg} / \mathrm{kg} \mathrm{b} \mathrm{wt}$. [20].

\subsubsection{Experiment 4}

Nitroxynil 34\% (HEPANIL34 ${ }^{\circledR}$ ) was given subcutaneously at a dose of $10 \mathrm{mg} / \mathrm{kg}$ b.wt nine hours before intramuscular injection of cefoperazone in a dose of $20 \mathrm{mg} / \mathrm{kg} \mathrm{b}$ wt. [20].

\subsection{Blood sampling}

Five milliliter venous whole blood samples were taken. The sampling times were $0.083,0.166,0.25,0.5,1,2,4,6,8$, 12 and $24 \mathrm{~h}$ after treatment. Blood samples were left to clot; the clear sera were separated by centrifugation at 3000 r.p.m for 15 minutes and stored at $-20^{\circ} \mathrm{C}$ until assayed.

\subsection{Drug bioassay}

Concentrations of cefoperazone in samples were determined by the microbiological assay method described by [21], using Escherichia coli (ATCC 10536) as test organism [18]. The application of microbiological assay for measuring cefoperazone concentration is suitable [18]. Six wells were made at equal distances in standard Petri-dishes containing $25 \mathrm{ml}$ seeded agar. The wells were filled with $100 \mu \mathrm{l}$ of either the test samples or the cefoperazone standard 
concentrations. The plates were kept at room temperature for $2 \mathrm{~h}$ before being incubated at $37^{\circ} \mathrm{C}$ for $18 \mathrm{~h}$. Zones of inhibition were measured using micrometers and the cefoperazone concentrations in the test samples were calculated from the standard curve. Cefoperazone standard solution of concentrations of 0.5 to $100 \mu \mathrm{g} / \mathrm{ml}$ were prepared in antibiotic-free goats serum and phosphate buffer saline. Standard curves of cefoperazone were prepared in antibacterialfree goat serum by the appropriate serial dilution. The standard curve in goat serum was linear over the range from 0.5 to $100 \mu \mathrm{g} / \mathrm{ml}$ and the value of correlation coefficient (r) was 0.991 . The limit of quantification was $0.5 \mu \mathrm{g} / \mathrm{ml}$. Protein binding of cefoperazone was estimated according to [22].

\subsection{Pharmacokinetic and statistical analysis}

Following IV administration, the serum concentration versus time data of cefoperazone was fitted to a twocompartment open model system according to the following biexponential equation:

$\mathrm{Cp}=\mathrm{Ae}-\alpha \mathrm{t}+\mathrm{Be}-\beta \mathrm{t}$

Where $\mathrm{Cp}$ is the concentration of drug in the serum at time t, A and B are the zero-time drug intercepts of the

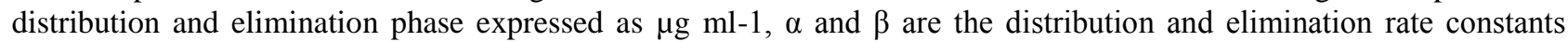
expressed in units of reciprocal time (h-1), and e is the natural logarithm base.

A pharmacokinetic computer program (R-strip, Micro-math, Scientific software, USA) was used to analyse the concentration-time curves for each individual animal after the administration of cefoperazone by different routes. Following I.V. and I.M. administrations. The appropriate pharmacokinetic model was determined by visual examination of individual concentration-time curves, and by application of Akaike's information criterion (AIC) [23]. All statistical analysis were carried out according to [24].

\section{Results}

The mean serum concentration of cefoperazone in goats following IV injection of $20 \mathrm{mg} / \mathrm{kg}$ are summarized in (Fig. 1). The pharmacokinetic parameters of cefoperazone in goats following IV administration of $20 \mathrm{mg} / \mathrm{kg}$ are summarized in (Table 1). Following IV administration, cefoperazone has moderate distribution in the body of goats with $\mathrm{Vd}_{\mathrm{ss}}$ of $0.44 \pm$ $0.03 \mathrm{~L} / \mathrm{kg}$. Cefoperazone was rapidly eliminated $\left(\mathrm{T}_{0.5(\beta)}: 1.97 \pm 0.14 \mathrm{~h}\right.$ ) from the body.

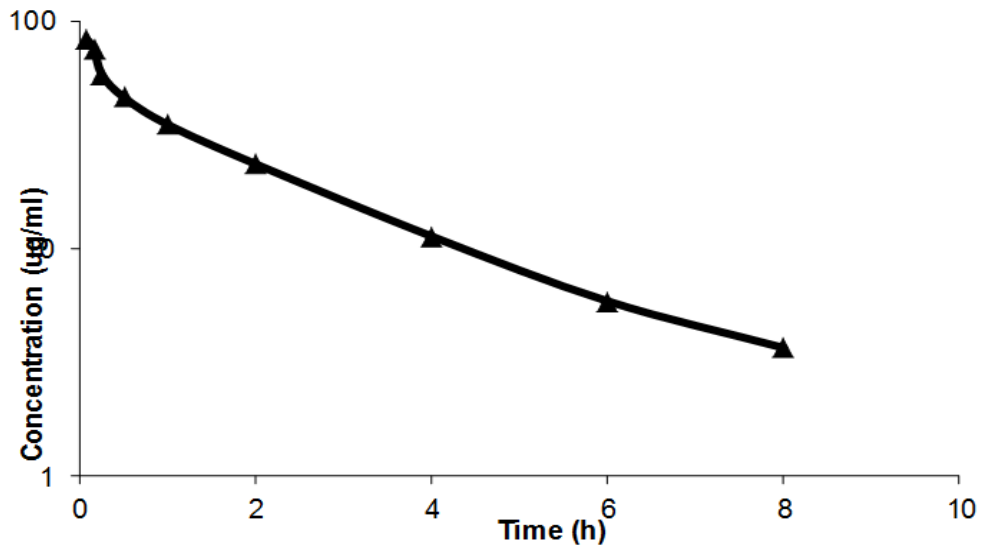

Fig. 1: Semi-Logarithmic Graph Depicting the Time-Concentrations Course of Cefoperazone in Serum of Goats (N=5) Following a Single Intramuscular Administration of $20 \mathrm{Mg} / \mathrm{Kg}$ Body Weight.

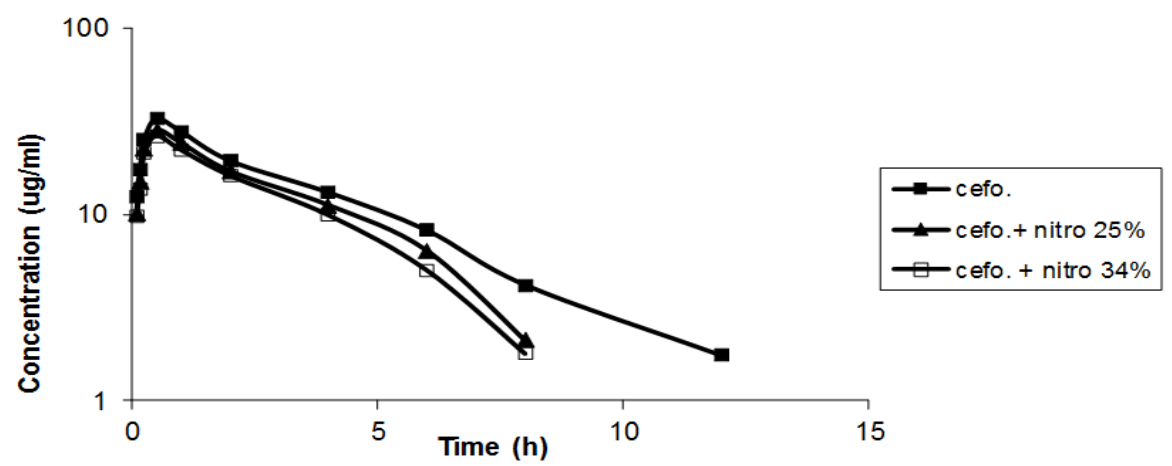

Fig. 2: Semi-Logarithmic Graph Depicting the Time-Concentrations Course of Cefoperazone in Serum Following a Single Intramuscular Administration of $20 \mathrm{Mg} / \mathrm{Kg}$ b.wt. to Non-Treated, Nitroxynil 25\% (10 Mg/Kg b.wt. SC) and Nitroxynil $34 \%$ (10 Mg/Kg b.wt. SC) Treated Goats (Mean $\pm \mathrm{SE}, \mathrm{N}=5$ ). 
Table 1: Mean ( \pm SE) Kinetic Parameters of Cefoperazone $(20 \mathrm{Mg} / \mathrm{Kg})$ Following a Single Intravenous Injection in Goats $(\mathrm{N}=5)$.

\begin{tabular}{|c|c|c|}
\hline PARAMETER & UNIT & MEAN $( \pm$ SE $)$ \\
\hline $\mathrm{Cp}^{\circ}$ & $\mu \mathrm{g} \cdot \mathrm{ml}^{-1}$ & $102.31 \pm 7.22$ \\
\hline A & $\mu \mathrm{g} \cdot \mathrm{ml}^{-1}$ & $54.10 \pm 4.38$ \\
\hline$\alpha$ & $\mathrm{h}^{-1}$ & $4.59 \pm 0.31$ \\
\hline $\mathrm{T}_{0.5(\alpha)}$ & $\mathrm{h}$ & $0.15 \pm 0.002$ \\
\hline $\mathrm{Vc}$ & $\mathrm{L} \mathrm{kg}^{-1}$ & $0.20 \pm 0.005$ \\
\hline $\mathrm{Vd}_{\text {area }}$ & $\mathrm{L} \mathrm{kg}^{-1}$ & $0.38 \pm 0.02$ \\
\hline $\mathrm{Vd}_{\mathrm{ss}}$ & $\mathrm{L} \mathrm{kg}^{-1}$ & $0.44 \pm 0.03$ \\
\hline $\mathrm{Vd}_{(\mathrm{B})}$ & $\mathrm{L} \mathrm{kg}^{-1}$ & $0.41 \pm 0.01$ \\
\hline $\mathrm{K}_{12}$ & $h^{-1}$ & $2.59 \pm 0.04$ \\
\hline $\mathrm{K}_{21}$ & $h^{-1}$ & $2.15 \pm 0.04$ \\
\hline $\mathrm{K}_{\mathrm{el}}$ & $\mathrm{h}^{-1}$ & $0.75 \pm 0.05$ \\
\hline B & $\mu \mathrm{g} \cdot \mathrm{ml}^{-1}$ & $48.20 \pm 3.89$ \\
\hline$\beta$ & $\mathrm{h}^{-1}$ & $0.35 \pm 0.005$ \\
\hline $\mathrm{T}_{0.5(\beta)}$ & $\mathrm{h}$ & $1.97 \pm 0.14$ \\
\hline AUC & $\mu \mathrm{g} \mathrm{ml}^{-1} \mathrm{~h}^{-1}$ & $141.21 \pm 8.61$ \\
\hline MRT & $\mathrm{h}$ & $2.15 \pm 0.12$ \\
\hline $\mathrm{Cl}_{\text {tot }}$ & $\mathrm{ml} / \mathrm{min} / \mathrm{kg}$ & $2.17 \pm 0.10$ \\
\hline
\end{tabular}

$\mathrm{Cp}^{\circ}$ : Concentration at zero-time; A,B: Zero-time intercepts of the biphasic disposition curve; $\alpha, \beta$ : Hybrid rate constants representing the slopes of distribution and elimination phases, respectively; $\mathrm{K}_{12}$ : First-order constant for transfer from central to peripheral compartment; $\mathrm{K}_{21}$ : First-order constant for transfer from peripheral to central compartment; $\mathrm{K}_{\mathrm{el}}$ : Elimination rate constant; $\mathrm{T}_{0.5(\alpha)}$ : Distribution half-life; $\mathrm{T}_{0.5(\beta)}$ : Elimination half-life; $\mathrm{AUC}_{(0-24)}$ : Area under serum concentration-time curve; MRT: Mean residence time; Vc: Apparent volume of central compartment; $\mathrm{Vd}_{\text {area }}: \mathrm{Apparent}$ volume of distribution calculated by area method $\mathrm{Vd}_{\mathrm{ss}}$ : Volume of distribution at steady state: $\operatorname{Vd}_{(\mathrm{B})}$ : Apparent volume of distribution calculated by extrapolation method; $\mathrm{Cl}_{\text {tot }}$ : Total body clearance.

The mean serum concentration of cefoperazone in goats following IM injection of $20 \mathrm{mg} / \mathrm{kg}$ alone, pretreated with nitroxynil (25\%) subcutaneously at a dose rate of $10 \mathrm{mg} / \mathrm{kg}$ and /or pretreated with nitroxynil (34\%) subcutaneously at a dose rate of $10 \mathrm{mg} / \mathrm{kg}$ are summarized in (Fig. 1). These data are best fitted to a two-compartment open model.

Following intramuscular injection of cefoperazone in a dose of $20 \mathrm{mg} / \mathrm{kg} \mathrm{b}$.wt, the drug was detected in serum $5 \mathrm{~min}$. post-injection $(12.48 \pm 0.67 \mu \mathrm{g} / \mathrm{ml})$, whereas its lowest level $(1.75 \pm 0.11 \mu \mathrm{g} / \mathrm{ml})$ was detected $12 \mathrm{~h}$. post-injection. No cefoperazone could be detected thereafter. Goats pre-treated with nitroxynil (25\%) at a dose of $10 \mathrm{mg} / \mathrm{kg}$ b.wt, subcutaneously or nitroxynil (34\%) at a dose of $10 \mathrm{mg} / \mathrm{kg}$ b.wt, subcutaneously showed a significant decrease in serum cefoperazone concentration level as compared to non-anthelmintic treated goats. cefoperazone concentration was only detected up to $8 \mathrm{~h}$. post-administration in nitroxynil (25\% and $34 \%)$ treated goats.

The pharmacokinetic values of cefoperazone in goats following IM injection of $20 \mathrm{mg} / \mathrm{kg}$ alone, pretreated with nitroxynil (25\%) subcutaneously at a dose rate of $10 \mathrm{mg} / \mathrm{kg}$ and /or pretreated with nitroxynil (34\%) subcutaneously at a dose rate of $10 \mathrm{mg} / \mathrm{kg}$ are summarized in (Table 2).

Table 2: Kinetic Parameters of Cefoperazone Following a Single Intramuscular Administration of $20 \mathrm{Mg} / \mathrm{Kg}$ b.wt. to Non-Treated, Nitroxynil 25\% (10 Mg/Kg b.wt. SC) and Nitroxynil 34\% (10 Mg/Kg b.wt. SC) Treated Goats (Mean \pm SE, N = 5).

\begin{tabular}{lllll}
\hline \multirow{2}{*}{ PARAMETER } & UNIT & CEFO (IM) & $\begin{array}{l}\text { CEFO (IM) + NITRO } \\
25 \%\end{array}$ & $\begin{array}{l}\text { CEFO (IM) + NITRO } \\
34 \%\end{array}$ \\
\hline $\mathrm{K}_{\mathrm{ab}}$ & $\mathrm{h}^{-1}$ & $5.64 \pm 0.41$ & $5.61 \pm 0.52$ & $5.57 \pm 0.48$ \\
$\mathrm{~T}_{0.5(\mathrm{ab})}$ & $\mathrm{h}$ & $0.13 \pm 0.01$ & $0.12 \pm 0.008$ & $0.12 \pm 0.01$ \\
$\mathrm{~K}_{\mathrm{el}}$ & $\mathrm{h}^{-1}$ & $0.27 \pm 0.02$ & $0.31 \pm 0.01$ & $0.33 \pm 0.02$ \\
$\mathrm{~T}_{0.5(\mathrm{el})}$ & $\mathrm{h}$ & $2.65 \pm 0.12$ & $2.21 \pm 0.10^{*}$ & $2.12 \pm 0.13^{*}$ \\
$\mathrm{C}_{\max }$ & $\mu \mathrm{g} \cdot \mathrm{ml}^{-1}$ & $31.42 \pm 1.03$ & $25.73 \pm 1.11^{* *}$ & $24.12 \pm 1.32^{* * *}$ \\
$\mathrm{~T}_{\max }$ & $\mathrm{h}$ & $0.58 \pm 0.02$ & $0.57 \pm 0.01$ & $0.56 \pm 0.04$ \\
$\mathrm{AUC}$ & $\mu \mathrm{g} \cdot \mathrm{h} \cdot \mathrm{ml}^{-1}$ & $123.13 \pm 4.59$ & $99.85 \pm 4.13^{* *}$ & $94.62 \pm 6.91^{*}$ \\
$\mathrm{MRT}$ & $\mathrm{h}$ & $3.34 \pm 0.23$ & $2.68 \pm 0.18$ & $2.61 \pm 0.20^{*}$ \\
$\mathrm{IBD}$ & $\mathrm{h}$ & $13.51 \pm 1.03$ & $11.42 \pm 1.21$ & $10.67 \pm 0.94$ \\
$\mathrm{~F}$ & $\%$ & $87.20 \pm 3.24$ & $70.71 \pm 3.11^{* *}$ & $67.01 \pm 2.53^{* * *}$ \\
\hline
\end{tabular}

$* \mathrm{p}<0.05 * * \mathrm{p}<0.01 * * * \mathrm{p}<0.005$ Significantly different

A: Zero-time intercept of distribution phase; $\mathrm{K}_{\mathrm{ab}}$ : First-order absorption rate constant; $\mathrm{T}_{0.5(\mathrm{ab})}$ : Absorption half-life; $\mathrm{B}$ : Zero-time intercept of elimination phase; $\mathrm{K}_{\mathrm{el}}$ : First-order elimination rate constant; $\mathrm{T}_{0.5 \text { (el) }}$ : Elimination half-life; $\mathrm{C}_{\mathrm{max}}$ : Maximum serum concentration; $\mathrm{T}_{\max }$ : Time to peak serum concentration; $\mathrm{AUC}_{(0 \text {-inf) }}$ : Area under serum concentrationtime curve; MRT: Mean residence time; IBD: Interval between doses. 
These data revealed that both nitroxynil (25\%) and nitroxynil (34\%) administration, negatively affected most of the cefoperazone parameters. In this respect, the elimination half-life $\mathrm{T}_{0.5 \text { (el) }}, \mathrm{C}_{\mathrm{max}}, \mathrm{AUC}$ and the systemic bioavailability ( $\mathrm{F}$ $\%)$ are significantly decreased in both group of nitroxynil-treated goats compared to anthelmintic-free goats

\section{Discussion}

Following IV administration of cefoperazone in goats at a dose of $20 \mathrm{mg} / \mathrm{kg}$, no adverse effects or toxic manifestation was observed. The results revealed that serum cefoperazone concentration versus time decreased in a bi-exponential manner, demonstrating the presence of distribution and elimination phases and justifying the use of two-compartment open model. This finding is in agreement with cefoperazone in horse [13], in dog [14] and in cross bred calves [17]. The drug was rapidly distributed with a short $\mathrm{T}_{0.5(\alpha)}: 0.15 \mathrm{~h}$. This value was close to those reported in calves $\left(\mathrm{T}_{0.5(\alpha)}: 0.15 \mathrm{~h}\right)$ [25] and $\operatorname{dog}\left(\mathrm{T}_{0.5(\alpha)}: 0.20 \mathrm{~h}\right)$ [14], shorter than those reported in sheep $\left(\mathrm{T}_{0.5(\alpha)}: 0.53 \mathrm{~h}\right)$ [19].

The elimination half-life and MRT were 1.97 and $2.15 \mathrm{~h}$, respectively, the results were near to those reported in cross bred calves 2.05 and $2.28 \mathrm{~h}$, respectively [17] and in dog 1.40 and $1.55 \mathrm{~h}$, respectively [14], shorter than those reported in sheep 3.80 and $3.29 \mathrm{~h}$, respectively [19]. The value of $\mathrm{Vd}_{\mathrm{ss}}(0.44 \mathrm{~L} / \mathrm{kg})$ indicated moderate extravascular distribution of the drug. This value was close to those reported in sheep $\mathrm{Vd}_{\mathrm{ss}}: 0.51 \mathrm{~L} / \mathrm{kg}$ [19]. The total body clearance of cefoperazone following IV administration was $2.17 \mathrm{ml} / \mathrm{min} / \mathrm{kg}$. The value was close to those reported in dog 1.96 $\mathrm{ml} / \mathrm{min} / \mathrm{kg}$ [14], while it is slower than $5.16 \mathrm{ml} / \mathrm{min} / \mathrm{kg}$ reported in sheep [19], $8.16 \mathrm{ml} / \mathrm{min} / \mathrm{kg}$ reported in unweaned calves [12] and $11.50 \mathrm{ml} / \mathrm{min} / \mathrm{kg}$ reported in cross bred calves [17].

Following IM administration of cefoperazone in goats at a dose of $20 \mathrm{mg} / \mathrm{kg}$, the drug was very rapidly absorbed with a short absorption half-life $\mathrm{T}_{0.5(\mathrm{ab})}$ of $0.13 \mathrm{~h}$. This value was shorter than those reported in $\operatorname{dog} 0.48 \mathrm{~h}$ [14]. The maximum serum concentration $\left(\mathrm{C}_{\max }\right)$ of $31.42 \mu \mathrm{g} \cdot \mathrm{ml}^{-1}$ was attained at $\left(\mathrm{T}_{\max }\right) 0.58 \mathrm{~h}$ post administration. However, lower value of $\mathrm{C}_{\max }$ like $25.67 \mu \mathrm{g} . \mathrm{ml}^{-1}$ at $0.5 \mathrm{~h}$ in sheep [19], $24.5 \mu \mathrm{g} \cdot \mathrm{ml}^{-1}$ at $1.5 \mathrm{~h}$ in dog [14] and $9.76 \mu \mathrm{g} . \mathrm{ml}^{-1}$ at $0.75 \mathrm{~h}$ in cross bred calves [18].

The elimination half-life of cefoperazone following i.m. administration was $2.65 \mathrm{~h}$. This value was close to those reported in unweaned calves $2.28 \mathrm{~h}$ [12], dog $2.24 \mathrm{~h}$ [14] and cross bred calves $2.31 \mathrm{~h}$ [18]. While it is shorter than value reported in sheep $3.32 \mathrm{~h}$ [19]. The mean residence time (MRT) was $3.34 \mathrm{~h}$. This value was similar to those reported in cross bred calves $3.62 \mathrm{~h}$ [18]. However it is shorter than value reported in sheep $4.27 \mathrm{~h} \mathrm{[19]} \mathrm{and} \mathrm{dog} \mathrm{4.05} \mathrm{h}$ [14], but longer than value recorded in unweaned calves $2.34 \mathrm{~h} \mathrm{[12].}$

The value of systemic bioavailability $(87.20 \%)$ indicated good absorption of cefoperazone from IM injection site. This value was higher than those reported in unweaned calves 76.3\% [12] and sheep 71.83\% [19]. While this value was close to those reported for cefepime in goats $86.45 \%$ [26] and ewes $86.8 \%$ [27]. High bioavailability of cefoperazone and maintenance of therapeutic concentration up to $12 \mathrm{~h}$ after IM administration suggests that the drug is suitable for IM administration for the treatment of systemic bacterial infections in goats. In vitro protein binding was $20.34 \%$, compared with $24.9 \%$ reported in cross bred calves [18].

The serum level of $\geq 0.2 \mu \mathrm{g} \cdot \mathrm{ml}^{-1}$ for third generation cephalosporin is considered adequate against most sensitive bacteria, including enterobacteriaceae spp. [28]. However, a serum concentration of $0.25-2.0 \mu \mathrm{g} . \mathrm{ml}^{-1}$ has been reported as $\mathrm{MIC}_{90}$ of cephalosporin against animal pathogens [29]. In the present study an average value of $\mathrm{MIC}\left(1.0 \mu \mathrm{g} . \mathrm{ml}^{-1}\right)$ has been taken in to consideration. The drug was detected above MIC in serum up to 8 and $12 \mathrm{~h}$ following IV and IM administration, respectively.

The serum cefoperazone concentrations were significantly decreased at different time intervals in both nitroxynil (25\%) and nitroxynil (34\%) treated goats as compared to non-anthelmintic-treated goats. The present results were, too consistent with [30], who found that; goats pre-treated with rafoxamide at a dose of $7.5 \mathrm{mg} / \mathrm{kg}$ b.wt, subcutaneously or albendazole at a dose of $7.5 \mathrm{mg} / \mathrm{kg}$ b.wt orally showed a significant decrease in serum florfenicol concentration level as compared to non-anthelmintic-treated animals.

Co-administration of nitroxynil in both different concentration (25\% and 34\%) subcutaneously $9 \mathrm{~h}$ earlier to intramuscular injection of cefoperazone significantly shortened the elimination half-life $\mathrm{T}_{0.5 \text { (el) }}$ compared with that in non-anthelmintic treated goats. This finding is in agreement with [31]. Who found that the pretreatment of albendazole orally $1 \mathrm{~h}$ earlier to intramuscular injection of enrofloxacin significantly shortened the elimination half-life compared with that in control goats?

The kinetic parameters recorded in the present research revealed that cefoperazone behaved differently in both nitroxynil $(25 \%)$ and nitroxynil $(34 \%)$ treated goats as compared to non-anthelmintic-treated goats wheres $\mathrm{C}_{\max }$, AUC and $\mathrm{F} \%$ value, are significantly decreased. This finding is in agreement with [30]. In this respect, the enzyme induction leads to an increased rate of biotransformation and corresponding decrease in the availability of the parent drug and consequently may lead to alteration of kinetic parameters [32].

\section{Conclusion}

On the footing of this study, it was resolved, that nitroxynil (25\% and 34\%) administration causes significant alterations in the disposition kinetic of cefoperazone in goats that may enhance the rate of cefoperazone elimination from the body, 
consequently diminish its efficacy, and prompt the development of bacterial resistance. These findings recommend adjustment of cefoperazone dosage when concurrently used with nitroxynil. The dose must be correspondingly increased to compensate its expected decrease in bioavailability and blood level, with subsequent reduction in its antibacterial potency, and therapeutic efficacy. There is no any significance difference between both nitroxynil concentrations ( $25 \%$ and $34 \%$ ) when co-administered with cefoperazone in goats.

\section{Conflict of Interest Statement}

The author declares that they have no conflict of interest.

\section{References}

[1] T.B. Barragry, Beta-lactam antibiotics. Veterinary Drug Therapy Lea \& Febiger, Philadelphia, PA., (1994) 221-240.

[2] A.L. Soraci, N. Mestorino and J. Errecalde, Concentration of Cefoperazone in synovial fluid and in bone after intramuscular administration. Revist. Med. Vet. Buen. Aire, (79) (1998) 148-150.

[3] S. Soback, A. Bor, R. Paz and G. Ziv, Clinical pharmacology of mecillinam in calves. Journal of Veterinary Pharmacology and Therapeutics, (9) (1986) 385-393. http://dx.doi.org/10.1111/j.1365-2885.1986.tb00059.x.

[4] L. Jiang, Q. Peng and Y. Yao, Penetration of ciprofloxacin and cefoperazone into human pancreas. Hua. Xi. Yi. Ke. Da. Xue. Xue. Bao. (28) (1997) 365-368.

[5] T. Bergan, Pharmacokinetic properties of the cephalosporins. Drugs, (34) (1987) 89-104. http://dx.doi.org/10.2165/00003495-19870034200008 .

[6] D. Wittman, Bone concentrations of six new betalactam antibiotics. $6^{\text {th }}$ International Cefoperazone Symposium. Program and Abstracts. AprilMay Tokyo. (1982) P 9.

[7] A.Q. Mckellar and D.B. Kinabo, The pharmacology of flukicidal drugs. British Veterinary Journal, (147) (1991) p. 306-321. http://dx.doi.org/10.1016/0007-1935(91)90003-6.

[8] M.A.O. Almeida and M.C.C. Ayres, Agentes anticestódeos e antitrematódeos. In: Spinosa, H.S.; Goniak, S.L.; Bernardi, M.M. Farmacologia Aplicada a Medicina Veterinária, 5a ed. Rio de Janeiro: Guanabara Koogan, cap. (44) (2011) p. 510-516.

[9] C.R. Reinemeyer and C.H. Courteny, Fármacos Anticestóides e antitrematóides. In: Adams, H.R. Farmacologia e terapêutica em veterinária, 8a ed. Rio de Janeiro: Guanabara Koogan, cap. (48) (2003) p. 819-828.

[10] A.F.T. Amarante, Profilaxia da verminose ovina, descontaminação de pastagens. In: Silva Sobrinho, A.G. (Ed.). Produção de Ovinos, Jaboticabal: FUNEP, cap. (18) (1990) p. 201-210.

[11] M.M. Bernardi, Exposição aos Medicamentos Durante o Período Perinatal. In: Spinosa, H.S.; Gorniak, S.L.; Bernardi, M.M. Farmacologia Aplicada a Medicina Veterinária, 4a ed. Rio de Janeiro: Guanabara Koogan, cap. (63) (2006) p. 807-816.

[12] S. Soback and G. Ziv, pharmacokinetics of Single doses of cefoperazone given by the intravenous and intramuscular routes to unweaned calves. Research in Veterinary Science, (47) (1989) 158-163.

[13] A.L. Soraci, N. Mestorino and J. Errecalde, Pharmacokinetics of cefoperazone in horses. Journal of Veterinary Pharmacology and Therapeutics, (19) (1996) 39-43. http://dx.doi.org/10.1111/j.1365-2885.1996.tb00006.x.

[14] C. Montesissa, R. Villa, P. Anfossic, R. Zanonic and S. Carlib, Pharmacodynamics and pharmacokinetics of cefoperazone and cefamandol in dogs following single dose i.v. and i.m. administration. Veterinary Journal, (166) (2003) 170-176. http://dx.doi.org/10.1016/S1090$\underline{0233(03) 00051-0 .}$.

[15] S. Goyal, R.K. Chaudhary and A.K. Srivastava, Pharmacokinetics of cefoperazone in buffalo calves following its intravenous administration. Journal of Veterinary Pharmacology and Toxicology, (3) (2003) 104-108.

[16] S. Goyal, R.K. Chaudhary and A.K. Srivastava, Pharmacokinetics following intramuscular administration and dosage regimen for cefoperazone in buffalo calves. Indian Journal of animal science, (75) (2005) 31-32.

[17] J.K. Gupta, R.K. Chaudhary and V.K. Dumka, Cefoperazone pharmacokinetics following single intravenous administration in cross bred calves. Israel Journal of Veterinary Medicine, (62) (2007) 87-90.

[18] J.K. Gupta, R.K. Chaudhary and V.K. Dumka, Pharmacokinetics after single intramuscular administration and in vitro plasma protein binding of Cefoperazone in cross bred calves. Veterinarski arhiv. (78) (2008) 441-448.

[19] H.H. Soni, R.J. Patel, K.A. Sadariya, S.S. Devada, S.K. Bhavsar and A.M. Thaker, Single dose pharmacokinetics of cefoperazone following intravenous and intramuscular administration in sheep. Israel Journal of Veterinary Medicine, (67) (2012) 220-224.

[20] G.C. Brander, D.M. Pugh, R.J. Baywater and W.L. Jenkins, Veterinary applied pharmacology and therapeutics. Fifth Ed., the English language Book Society and Boilliere, Trindall, London (1991).

[21] B. Arret, D. Johnson and A. Kirshboum, Outline of details for microbiological assay of antibiotics, second revision. Pharmacology Science, (60) (1971) 1689-1694.

[22] A.W. Craig and B. Suh, Protein binding and the antibacterial effects: methods for determination of protein binding. In: Lorian, V. (Ed), Antibiotics in Laboratory Medicine" Williams and Wilkins Baltimore, MD, (1980) pp. 265-297.

[23] K. Yamaoka, T. Nakagawa and T. Uno, Statistical moment in pharmacokinetics. Journal of Pharmacokinetic and Biopharmaceutics, (6) (1978) 547-558.

[24] G. W. Snedecor and T. Cochran, Statistical Methods $6^{\text {th }}$ ed. pp. Ames, lowa U.S.A., (1976) 502-503.

[25] S. Carli, C. Montesissa, O. Sonzogni and M. Madonna, Pharmacokinetics of sodium cefoperazone in calves. Pharmacological Research Communications, (18) (1986) 481-490. http://dx.doi.org/10.1016/0031-6989(86)90168-2.

[26] S. Prawez, R. Raina, D. Dimitrova, N. Pankaj, A. Ahanger and P. Verma, The pharmacokinetics of cefepime in goats following single-dose i.v. and i.m. administration. Turkish Journal of Veterinary and Animal Science, (34) (2010) 427-431.

[27] M. Ismail, Pharmacokinetics of cefepime administered by i.v and i.m. routes to ewes. Journal of Veterinary Pharmacology and Therapeutics, (28) (2005) 499-503. http://dx.doi.org/10.1111/j.1365-2885.2005.00689.x.

[28] S. Barriere and J. Flaherty, Third generation cephalosporins: A critical evaluation. Clinical Pharmacology, (3) (1984) 351-373.

[29] A.W. Craig, Pharmacokinetic/pharmacodynamic parameters. Rationale for antibacterial dosing of mice and men. Clinical Infectious Disease, (26) (1998) 1-12. http://dx.doi.org/10.1086/516284.

[30] M. Atef, A.Y. El-Gendi, M.M. Aziza and A.M. Abd El-Aty, Effect of three anthelmentics on disposition kinetics of florfenicol in goats. Food and Chemical Toxicology (48) (2010) 3340-3344. http://dx.doi.org/10.1016/j.fct.2010.08.039.

[31] K. Abo El-Sooud, Influence of albendazole on the disposition kinetics and milk antimicrobial equivalent activity of enrofloxacin in lactating goats. Pharmacological Research, 48 (2003) 389-395. http://dx.doi.org/10.1016/S1043-6618(03)00179-8.

[32] M. Goodman and A.G. Gilmans, The pharmacological basis of therapeutics. $9^{\text {th }}$ edition, Mc Graw - Hill Companies, (1995) pp. 14-15. 